\title{
Controlled killing of human cervical cancer cells by combined action of blue light and $\mathrm{C}$-doped $\mathrm{TiO}_{2}$ nanoparticles
}

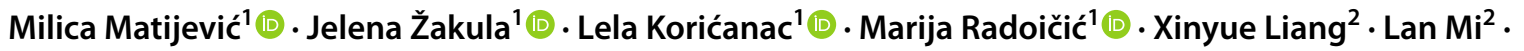

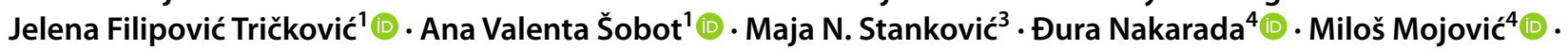 \\ Marijana Petković ${ }^{1}$ - Milutin Stepić ${ }^{1}$ (D) Maja D. Nešić ${ }^{1}$ (i)
}

Received: 14 April 2021 / Accepted: 30 July 2021 / Published online: 16 August 2021

(c) The Author(s), under exclusive licence to European Photochemistry Association, European Society for Photobiology 2021

\begin{abstract}
In this study, C-doped $\mathrm{TiO}_{2}$ nanoparticles $\left(\mathrm{C}-\mathrm{TiO}_{2}\right)$ were prepared and tested as a photosensitizer for visible-light-driven photodynamic therapy against cervical cancer cells (HeLa). X-ray diffraction and Transmission Electron Microscopy confirmed the anatase form of nanoparticles, spherical shape, and size distribution from 5 to $15 \mathrm{~nm}$. Ultraviolet-visible light spectroscopy showed that $\mathrm{C}$ doping of $\mathrm{TiO}_{2}$ enhances the optical absorption in the visible light range caused by a bandgap narrowing. The photo-cytotoxic activity of $\mathrm{C}-\mathrm{TiO}_{2}$ was investigated in vitro against $\mathrm{HeLa}$ cells. The lack of dark cytotoxicity indicates good biocompatibility of $\mathrm{C}-\mathrm{TiO}_{2}$. In contrast, a combination with blue light significantly reduced the survival of HeLa cells: illumination only decreased cell viability by $30 \%$ (15 min of illumination, $120 \mu \mathrm{W}$ power), and $60 \%$ when HeLa cells were preincubated with $\mathrm{C}-\mathrm{TiO}_{2}$. We have also confirmed blue light-induced $\mathrm{C}$ - $\mathrm{TiO}_{2}$-catalyzed generation of reactive oxygen species in vitro and intracellularly. Oxidative stress triggered by $\mathrm{C}-\mathrm{TiO}_{2} /$ blue light was the leading cause of HeLa cell

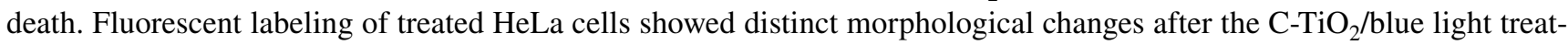
ment. Unlike blue light illumination, which caused the appearance of large necrotic cells with deformed nuclei, cytoplasm swelling, and membrane blebbing, a combination of $\mathrm{C}-\mathrm{TiO}_{2} /$ blue light leads to controlled cell death, thus providing a better outcome of local anticancer therapy.
\end{abstract}

\section{Graphic abstract}

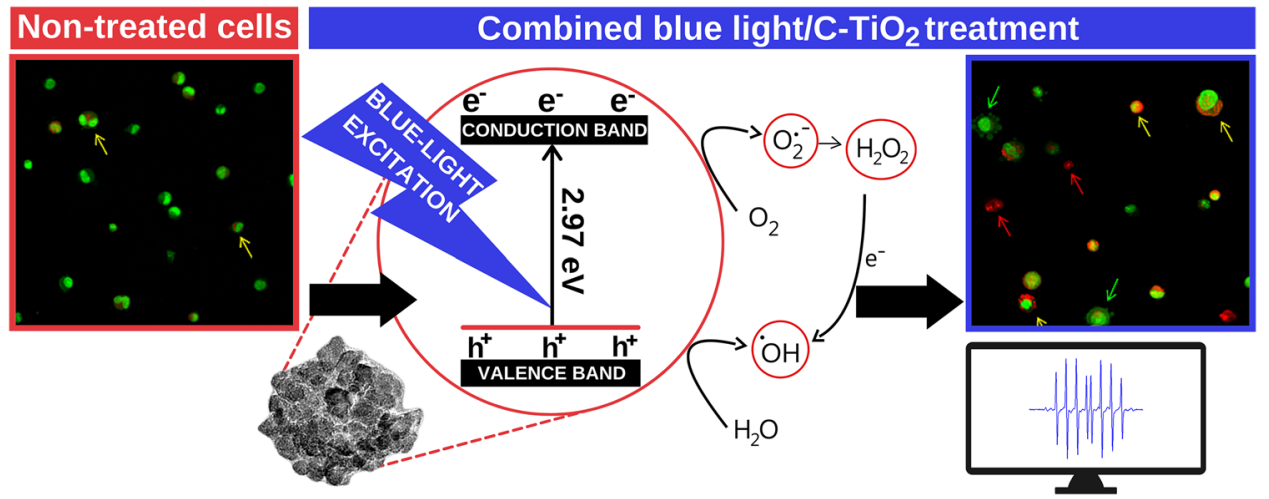

Keywords C-doped $\mathrm{TiO}_{2} \cdot$ Photodynamic therapy $\cdot$ Blue light $\cdot \mathrm{HeLa} \cdot$ Autophagy $\cdot$ Reactive oxygen species

Milica Matijević

milica.m@vin.bg.ac.rs

Extended author information available on the last page of the article

\section{Abbreviations}

'OH ANOVA : Analysis of variance AO Acridine orange ATCC American Type Culture Collection 


$\begin{array}{ll}\text { AVOs } & \text { Acidic vesicular organelles } \\ \text { CB } & \text { Conduction band } \\ \text { C-TiO } & \text { Carbon-doped titanium dioxide } \\ \text { DCF } & \text { Dichlorofluorescein } \\ \text { DCFH-DA } & \text { 2,7-Dichlorofluorescein diacetate } \\ \text { DEPMPO } & \text { 5-(Diethoxyphosphoryl)-5-methyl-1-pyrro- } \\ & \text { line-N-oxide } \\ \text { DIC } & \text { Differential interference contrast } \\ \text { DMEM } & \text { Dulbecco's Modified Eagle's Medium } \\ \text { EDTA } & \text { Ethylenediaminetetraacetic acid } \\ \text { EPR } & \text { Electron paramagnetic spectroscopy } \\ \text { FBS } & \text { Fetal bovine serum } \\ \mathrm{H}_{2} \text { DCFDA } & \text { 2',7'-Dichlorodihydrofluorescein diacetate } \\ \text { HeLa } & \text { Henrietta Lacks (in the text referred to the } \\ & \text { human epithelial cervical cancer cells) } \\ \text { HRTM } & \text { High-resolution transmission electron } \\ & \text { microscopy } \\ \text { LSCM } & \text { Laser scanning confocal microscopy } \\ \text { MTT } & \text { 3-(4,5-Dimethylthiazol-2-yl)-2,5-diphe- } \\ & \text { nyl-2H-tetrazolium bromide } \\ \text { NPs } & \text { Nanoparticles } \\ \text { PBS } & \text { Phosphate-buffered saline } \\ \text { PDT } & \text { Photodynamic therapy } \\ \text { PI } & \text { Propidium iodide } \\ \text { PS } & \text { Photosensitizer } \\ \text { RCF } & \text { Relative centrifugal force } \\ \text { ROS } & \text { Reactive oxygen species } \\ \text { SRB } & \text { Sulforhodamine B } \\ \text { TBHB } & \text { Tert-butyl hydroperoxide } \\ \text { TEM } & \text { Transmission electron microscopy } \\ \text { TiO } & \text { Titanium dioxide } \\ \text { UV } & \text { Ultraviolet } \\ \text { UV-Vis } & \text { Ultraviolet-visible light } \\ \text { VB } & \text { Valence band } \\ \text { XRPD } & \text { X-ray powder diffraction } \\ & \end{array}$

\section{Introduction}

$\mathrm{TiO}_{2}$ nanoparticles (NPs) have great potential for various biological applications, such as drug delivery [1-3], cell imaging [2, 4, 5], biosensors [6-8], and photodynamic therapy (PDT) $[2,9,10]$. In recent years, PDT has been vastly explored as less damaging to normal tissues than surgery, radiation, or chemotherapy to treat various cancer types. PDT employs the photosensitizer (PS), which in the presence of molecular oxygen exhibits photo-cytotoxic activity by generating reactive oxygen species (ROS). In other words, upon light irradiation, PS triggers a set of chemical reactions that produce ROS resulting in cells' death by necrosis, apoptosis, and/or autophagy. PDT has demonstrated its advantages for treating surface tumors such as melanoma. The most important are: no scarring effect after healing, tolerance to repeated doses, and no need for significant investments for its implementation and maintenance [11]. Nevertheless, PDT is not restricted to melanoma cancer treatment, as the optical fiber may be applied for selective illumination at the site of challenging accessible tumors. Considering that only a colposcope for the laser optical path is required to access the cervical tumor, PDT has been successfully applied in clinics for carcinoma in situ and dysplasia of the uterine cervix [12]. As it may preserve fertility and is more comfortable, this therapy is an excellent alternative to the clinically used treatments for eliminating cervical cancer, known as the third most common cause of cancer incidence and mortality in women worldwide [13]. However, clinically applied PDT treatments have two significant drawbacks: PSs internalize in normal and tumor cells unselectively and have demonstrated undesired dark cytotoxicity.

Hence, metal oxide semiconductor-based NPs have drawn much attention as possible PSs and cytostatic carriers. They exhibit unique chemical and physical properties due to the high density and limited size of corner or edge on the surface site and have a large surface-to-volume ratio, photo-responsivity, and possibility of surface modification. The most investigated nano-sized metal oxides for PDT are mesoporous $\mathrm{SiO}_{2}, \mathrm{TiO}_{2}$, and $\mathrm{ZnO}$. For our investigations, we have selected $\mathrm{TiO}_{2}$, typical n-type semiconductor material, as it is cost-effective, photo-stable, and chemically inert. Furthermore, multiple studies have confirmed that photoexcited $\mathrm{TiO}_{2}$ NPs effectively eliminate cancer cells [14-16]. Still, this therapy might be challenging to implement in clinical applications because of the high bandgap energy $(3.2 \mathrm{eV})$ and the necessity to apply UV light for photo-stimulation. In addition to being harmful, UV light cannot penetrate deeply through human tissues; thus, $\mathrm{TiO}_{2}$-based photo-therapy is restricted to near-to-surface tumors. Therefore, modifications of $\mathrm{TiO}_{2}$ to extend its responsiveness to visible light have become one of the most important goals to increase the applications of $\mathrm{TiO}_{2}$. Doping of NPs, particularly with p-block elements, is one option to modify the photodynamic response of $\mathrm{TiO}_{2}$ by shifting the bandgap to lower energies, i.e., to the visible light region [17-19]. Whereas nitrogen doping is the most studied approach [17, 20,21], carbon(C)doping remains less explored up to date [22, 23].

In this work, we have produced $\mathrm{C}$-doped $\mathrm{TiO}_{2} \mathrm{NPs}$ (denoted as $\mathrm{C}-\mathrm{TiO}_{2}$ ), for which we have shown that they are biocompatible yet effective as a PS in the light-driven treatment of the human cervical cancer cells line-HeLa. Furthermore, we have tested $\mathrm{C}-\mathrm{TiO}_{2}$ photosensing properties in the visible region using blue light to reach the absorption efficacity of $\mathrm{C}-\mathrm{TiO}_{2}$. For these NPs, we determined morphology, surface properties, and optical properties. Moreover, in vitro cytotoxicity, photo-cytotoxicity, cell internalization, and morphology of HeLa cells were investigated after treatment and illumination. The combined therapeutic effect was 
compared through MTT assay, SRB assay, laser scanning confocal microscopy (LSCM), and fluorescence microscopy. Furthermore, we studied ROS production by electron paramagnetic spectroscopy (EPR) and ROS cell assay as the possible involved mechanisms for the photokilling effect by $\mathrm{C}-\mathrm{TiO}_{2}$.

\section{Materials and methods}

\section{1 ${\mathrm{C}-\mathrm{TiO}_{2}}_{2}$ synthesis}

We prepared $\mathrm{C}-\mathrm{TiO}_{2}$ by the method reported by Ren et al. [24] from amorphous $\mathrm{TiO}_{2}$ NPs, which were produced by controlled hydrolysis of titanium isopropoxide $(97 \%$, Aldrich) in ethanol. Briefly, ethanol was mixed with $0.1 \mathrm{M}$ aqueous $\mathrm{KCl}$ solution, followed by adding $2.2 \mathrm{~mL}$ of titanium isopropoxide under magnetic stirring. The white precipitate was formed after stirring for $10 \mathrm{~min}$ and left for $24 \mathrm{~h}$ (aging). First, the suspension was collected by filtration and over-dried at $60{ }^{\circ} \mathrm{C}$. Next, $\mathrm{C}-\mathrm{TiO}_{2}$ was synthesized by thermal treatment of the mixture of amorphous $\mathrm{TiO}_{2}$ and glucose (22:1 mass ratio) at $160{ }^{\circ} \mathrm{C}$ for $12 \mathrm{~h}$. After cooling, the product was collected, washed with water and ethanol, and dried at $60{ }^{\circ} \mathrm{C}$.

\subsection{Characterization of $\mathrm{C}^{-\mathrm{TiO}_{2}}$}

X-ray powder diffraction (XRPD) analysis was carried out with a Philips PW 1050 diffractometer described in [25]. The diffraction patterns were collected at $25^{\circ} \mathrm{C}$ with a scanning step of $0.05^{\circ}$ and a dwell time of $50 \mathrm{~s}$. The size, shape, and appearance of the $\mathrm{TiO}_{2}$ NPs were checked by transmission electron microscopy, TEM (JOEL JEM-2100F). The surface charge was measured by zeta potential (Zetasizer Nano ZS90, Malvern) in the manner we previously reported [10]. Finally, the optical properties of the C-TiO were checked with UV-Vis spectroscopy at the Perkin Elmer Lambda spectrophotometer.

\subsection{Cell culture}

HeLa cell line was obtained from American Type Culture Collection (ATCC, CCL-2). HeLa cells were incubated in Dulbecco`s Modified Eagle`s Medium (DMEM) supplemented with glucose $(4500 \mathrm{mg} / \mathrm{L})$, L-glutamine, $10 \%$ fetal bovine serum (FBS), penicillin, and streptomycin (10.000 $\mathrm{U} / \mathrm{mL}$ and $10 \mathrm{mg} / \mathrm{mL}$, respectively) and humidified under $37^{\circ} \mathrm{C}$ and $5 \% \mathrm{CO}_{2}$ (Heraeus, Hanau, Germany). Cells were grown until reaching $80 \%$ confluence with normal morphology for further experiments.

\subsection{Cyto- and photo-cytotoxicity of $\mathrm{C}^{-\mathrm{TiO}_{2}}$}

For the analysis of the concentration-dependent effect of the $\mathrm{C}-\mathrm{TiO}_{2}$, cells $\left(6.25 \times 10^{3}\right.$ cells $\left./ \mathrm{cm}^{2}\right)$ were treated with three concentrations of $\mathrm{C}-\mathrm{TiO}_{2}$ suspension in ultrapure water in the 1:9 suspension to medium proportion $(\mathrm{v} / \mathrm{v})$, so the final treatments concentrations in the medium were 8 , 80 , and $160 \mu \mathrm{g} / \mathrm{mL}$. Treated cells were incubated for $48 \mathrm{~h}$.

To examine photo-cytotoxicity, we preincubated HeLa cells with the water suspension of $\mathrm{C}^{-\mathrm{TiO}_{2}}(160 \mu \mathrm{g} / \mathrm{mL})$ for $1 \mathrm{~h}$. For comparison, HeLa cells were treated and incubated with the same concentration of colloidal $\mathrm{TiO}_{2}$ NPs, which we had tested previously [3]. The cells were then exposed to blue light $(450 \mathrm{~nm}, 120 \mu \mathrm{W}$, power meter NOVA II, Ophir) for $15 \mathrm{~min}$. To obtain the specific wavelength of the light, we have used the shortpass $450 \mathrm{~nm}$ filter (ThorLabs), which transmitted the light from an incandescent light bulb $(100 \mathrm{~W})$ from 400 to $450 \mathrm{~nm}$. Two pieces of fused silica lenses formed the concentrated parallel light beams. Photo-cytotoxicity was determined after $48 \mathrm{~h}$. Three types of control were used: non-treated cells, C-TiO $\mathrm{T}_{2}$ without illumination, and illuminated cells.

For (photo-)cytotoxicity, all cell groups were assayed in triplicate in the three independently conducted experiments.

Cytotoxic effects of $\mathrm{C}-\mathrm{TiO}_{2}$ in HeLa cells were assessed and measured (microplate reader-Bio-TekSynergy ${ }^{\mathrm{TM}} \mathrm{HT}$, Bio-Tek® Instruments) by a modified MTT test by the procedure described earlier [10]. Cell viability upon light illumination was determined by a sulforhodamine B (SRB) assay described previously [26] by Wallac, VICTOR2 1420 Multilabel Counter, Perkin Elmer.

\subsection{HeLa cell C-TiO ${ }_{2}$ internalization by the imaging microscopy}

HeLa cells were grown in Petri dishes and, after reaching $80 \%$ confluence, the medium was replaced by a medium containing $\mathrm{C}^{-\mathrm{TiO}_{2}}(160 \mu \mathrm{g} / \mathrm{mL})$ and incubated for $1 \mathrm{~h}$. The cells were then washed three times with PBS, and the medium was replaced by a C-TiO ${ }_{2}$ free DMEM. The uptake of C-TiO ${ }_{2}$ by HeLa cells was observed by LSCM (Olympus, FV-300, IX71; Olympus, Tokyo, Japan) equipped with a $405 \mathrm{~nm}$ continuous laser excitation (Coherent, Palo Alto, USA $)$ and a water immersion objective $(\times 60, \mathrm{NA}=1.2)$. The images of $\mathrm{C}-\mathrm{TiO}_{2}$ were acquired through two channels: the reflecting signal was obtained with no filter, whereas, the cell morphology was obtained in a transmission channel by the differential interference contrast (DIC) micrographs. ImageJ software (Fiji) was applied for merging two channels and for the red-colored presentation of the NPs. The scanned area was $115 \times 115 \mu \mathrm{m}$, with a resolution of $512 \times 512$ pixels. 


\subsection{Cells' death modalities induced by $\mathrm{C}-\mathrm{TiO}_{2}$ and/ or blue light}

To get a better insight into the cells' death modalities, we have applied AO/PI cell staining method. First, HeLa cells were stained with acridine orange (AO) and propidium iodide (PI) according to standard procedures [27, 28]. Next, stained HeLa cells were analyzed under an epifluorescent microscope Axioimager A1 (Carl Zeiss, Jena, Germany) equipped with the ISIS imaging software package (MetaSystems, Altlussheim, Germany). Afterward, treated and illuminated cells were incubated for $48 \mathrm{~h}$ under the standard culture conditions. After that, cells were detached by trypsin (Trypsin-EDTA solution, Gibco), blocked with a medium supplemented with $10 \% \mathrm{FBS}$, transferred into tubes, and centrifuged for $5 \mathrm{~min}$ at $600 \times \mathrm{RCF}$, and washed with PBS. After adding the same volumes of each fluorescent dye $(10 \mu \mathrm{L}, 10 \mu \mathrm{g} / \mathrm{mL})$, the cell suspension was dropped onto microscopic slides, covered, and analyzed under the microscope within $15 \mathrm{~min}$. At least 100 cells per treatment were counted and analyzed.

\subsection{Visible light-driven ROS production of the $\mathrm{C}-\mathrm{TiO}_{2}$}

To assess the ROS production by EPR, we added DEPMPO (5-(Diethoxyphosphoryl)-5-methyl-1-pyrroline-N-oxide) [29] to the $\mathrm{C}-\mathrm{TiO}_{2}(1 \mu \mathrm{g} / \mathrm{mL})$ suspension in deionized water. Afterward, the mixture was transferred into the gas permeable Teflon tubes (Zeus Industries Inc., Orangeburg, USA) inserted into a special quartz tube in the EPR spectrometer (Bruker ELEXSYS-II E540, Germany) operating at X-band. EPR experimental settings were as follows: center field $3503.70 \mathrm{G}$, microwave power $10 \mathrm{~mW}$, modulation frequency $100 \mathrm{kHz}$, modulation amplitude $2 \mathrm{G}$, microwave frequency 9.85 GHz. During measurements, one sample was continuously irradiated with the visible light source $(120 \mu \mathrm{W})$, and the other was kept in the dark.

\subsection{Intracellular ROS production}

We have used Fluorometric Assay Kit (Elabsciences, Houston, TX, USA) to evaluate intracellular ROS levels. We measured the dichlorofluorescein's fluorescence (DCF), the intracellular hydrolysis and oxidation product of 2,7-dichlorofluorescein diacetate DCFH-DA. HeLa cells $\left(3.75 \times 10^{4}\right.$ cells $\mathrm{cm}^{-2}$, triplicate) were incubated with DMEM without phenol red (Biological Industries, Beit-Haemek) containing DCFH-DA and C-TiO ${ }_{2}$, treated and illuminated as described. After irradiation and cells' double washing with PBS, fluorescence was determined by measuring excitation absorbance and emission absorbance at $485 \mathrm{~nm}$ and $535 \mathrm{~nm}$ wavelengths, respectively. Tert-butyl hydroperoxide (TBHP), an analog of hydroperoxide, served as a positive control. The experiments were repeated three times independently, whereas each experiment was performed in triplicate.

\subsection{Statistical analysis}

Statistical differences between various treatments were assessed using one-way analysis of variance (ANOVA) with Tukey's multicomparison post-test using GraphPad Prism 8.0.1. P-values $<0.05$ were considered significant.

\section{Results and discussion}

\subsection{Size and crystalline structure of $\mathrm{C}^{-\mathrm{TiO}_{2}}$}

Figure 1(a) shows the TEM image of $\mathrm{C}^{-\mathrm{TiO}_{2}}$, whereas, Fig. 1(b) shows the high-resolution TEM (HRTM) image of $\mathrm{C}-\mathrm{TiO}_{2}$. The obtained images revealed a nearly spherical shape of the $\mathrm{C}-\mathrm{TiO}_{2}$ (average size 5-15 nm), with the lattice spacing of $0.35 \mathrm{~nm}$, corresponding to the anatase (101) plane. The anatase phase of $\mathrm{C}-\mathrm{TiO}_{2}$ was confirmed by XRPD, Fig. 1(c). All detected diffraction peaks represent the tetragonal anatase form of $\mathrm{TiO}_{2}$ [25]. Results show that $\mathrm{C}$-doping does not influence the crystal structure of neat $\mathrm{TiO}_{2}$. The peaks are sharp, with (101) of anatase as the highest peak (Fig. 1(c)). Thus, we suppose that these are the most exposed facets of the materials for any photo-driven reactions.

The electrical property of $\mathrm{C}-\mathrm{TiO}_{2}$ was determined by zeta potential, which is the indicator of colloidal stability (at $\mathrm{pH}=7.0$ ). Surface charge affects various biological processes associated with NPs, such as cellular uptake and cytotoxicity. The zeta potential of $\mathrm{C}-\mathrm{TiO}_{2}$ was $-11.0 \pm 0.6 \mathrm{mV}$, which refers to negatively charged NPs with incipient stability.

\subsection{Optical properties of $\mathrm{C}_{\mathrm{TiO}}$}

The absorbance spectra of undoped and C-doped $\mathrm{TiO}_{2}$ are presented in Fig. 2(a). The undoped $\mathrm{TiO}_{2}$ displayed an absorption edge at about $400 \mathrm{~nm}$. On the other hand, the $\mathrm{C}-\mathrm{TiO}_{2}$ showed an increase of the absorption broadband in the visible range, implying that the C-doping of $\mathrm{TiO}_{2}$ enhanced the optical absorption, especially in the blue-light wavelength range between 380 and $500 \mathrm{~nm}$. Moreover, we assume that the decrease of the energy bandgap is related to preventing electron-hole recombination and $\mathrm{Ti}-\mathrm{C}$ bond formation.

Bandgap narrowing in $\mathrm{C}^{-} \mathrm{TiO}_{2}$ was confirmed using the Tauc equation: 
Fig. 1 Crystalline structure of $\mathrm{C}_{-} \mathrm{TiO}_{2}$. TEM (a) and HRTM (b) image of $\mathrm{C}-\mathrm{TiO}_{2}$; (c) XRPD pattern of $\mathrm{C}-\mathrm{TiO}_{2}$
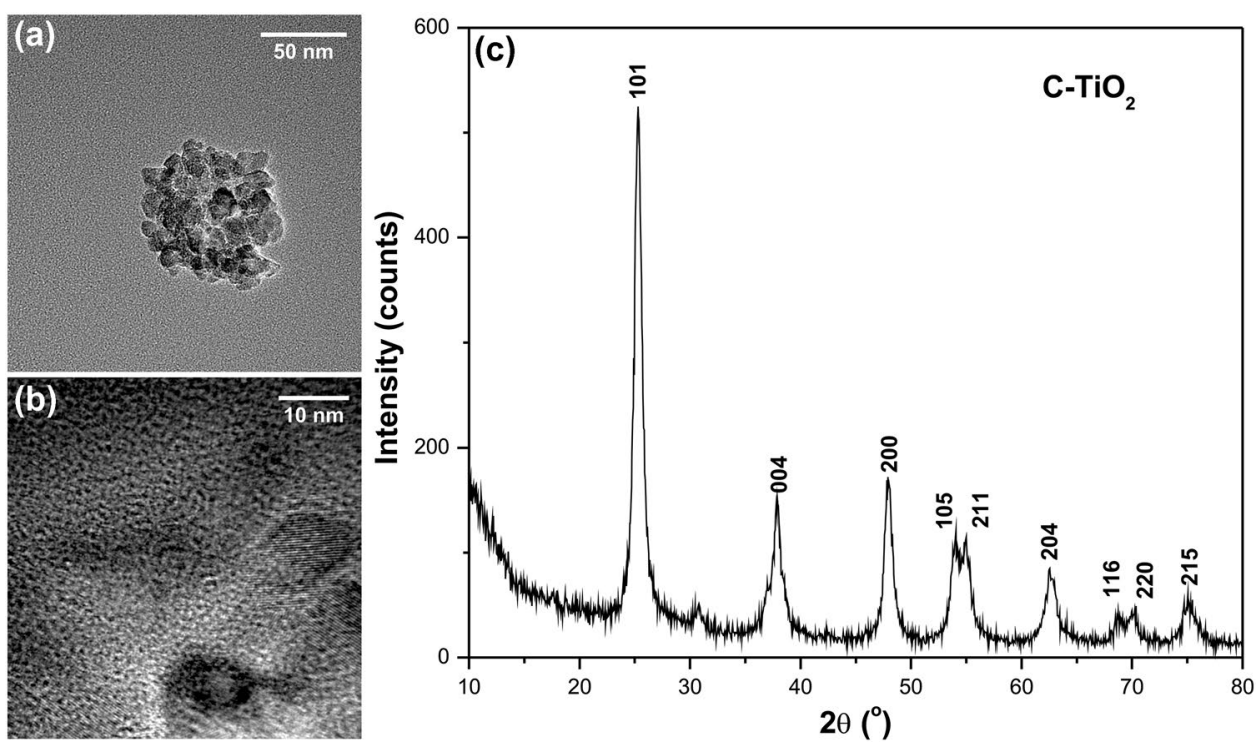

Fig. 2 Optical properties of pure $\mathrm{TiO}_{2}$ and $\mathrm{C}-\mathrm{TiO}_{2}$. UV-Vis absorption spectra of the $\mathrm{TiO}_{2}$ and $\mathrm{C}-\mathrm{TiO}_{2}$ (a) and optical bandgap calculation for non-doped and $\mathrm{C}-\mathrm{TiO}_{2}$ using the Tauc plot method for indirect-allowed transitions (b). A schematic representation of $\mathrm{C}-\mathrm{TiO}_{2}$ bandgap narrowing and production of ROS by irradiating with photons $(h v)$ having energies $\geq E g$. Eg stands for the bandgap energy between the valence band (VB) and the conduction band (CB) (c) (a)
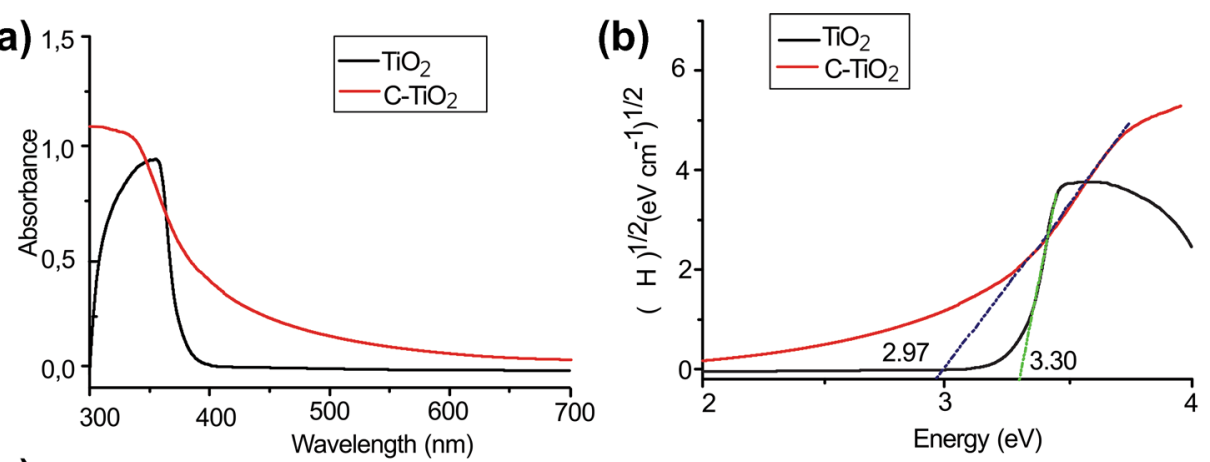

(c)
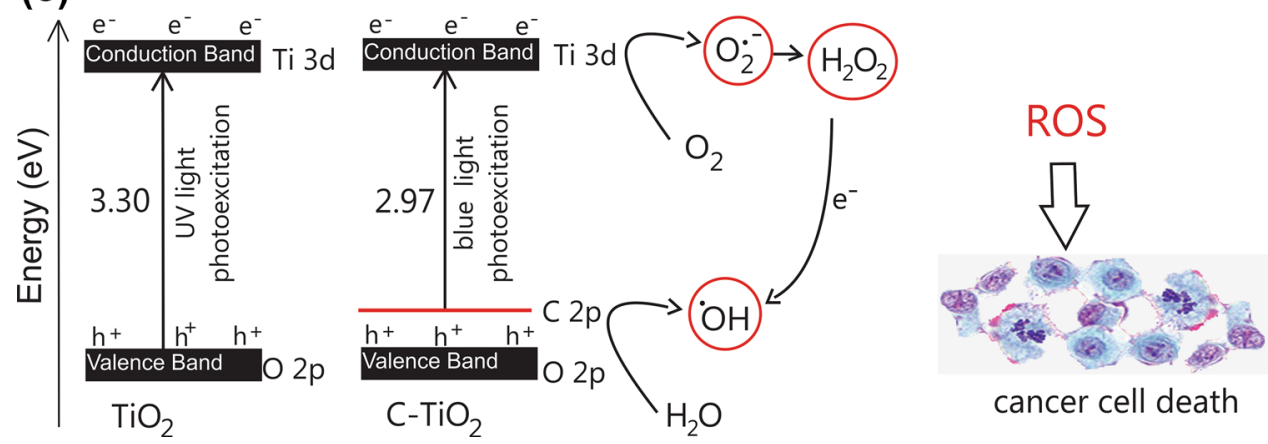

$(a h v)^{n}=A(h v-E g)$,

where $\alpha$ is the absorption coefficient, $\mathrm{A}$ is the absorption constant, and $\mathrm{n}$ indicates indirect $(n=1 / 2)$ or direct $(n=2)$ allowed transitions. The bandgap energy $(\mathrm{Eg})$ is determined using the optical absorption coefficient $\alpha$ from the experimental absorbance. The plot of the variation of $(\alpha h \nu)^{1 / 2}$ versus photon energy $(h \nu)$ from the spectra data of pure anatase $\mathrm{TiO}_{2}$ and $\mathrm{C}-\mathrm{TiO}{ }_{2}$ are presented in Fig. 2(b). Eg values are obtained by extrapolating the curve's linear region to the abscissa $(\alpha=0)$.
The evaluated bandgap of pure anatase $\mathrm{TiO}_{2}$ is $3.30 \mathrm{eV}$, which corresponds well to the other literature data [30, 31]. On the other hand, a direct interaction between $\mathrm{C}$ and $\mathrm{Ti}$ atoms on the surface of the NPs caused the bandgap narrowing of the $\mathrm{C}-\mathrm{TiO}_{2}$ as the obtained value was $2.97 \mathrm{eV}$. The literature suggests that bandgap narrowing by doping $\mathrm{TiO}_{2}$ with p-block elements results from the formed VB by mixing the dopant $\mathrm{p}$-states with the p-states of oxygen [32]. The energy bands of $\mathrm{TiO}_{2}$ and $\mathrm{C}-\mathrm{TiO}_{2}$ are shown in Fig. 2(c). The VB of $\mathrm{TiO}_{2}$ corresponds to O $2 \mathrm{p}$ states, and the CB corresponds to $\mathrm{Ti} 3 \mathrm{~d}$ states, whereas, the $\mathrm{VB}$ of $\mathrm{C}-\mathrm{TiO}_{2}$ is 
filled with $\mathrm{C} 2 \mathrm{p}$ states, and its position is above the $\mathrm{TiO}_{2}$ VB. The bandgap narrowing decreases electron transition energy between the VB and CB, shifting the photoresponse towards the blue region (Fig. 2(c)). It has been shown that nitrogen and carbon doping could cause the narrowing of the bandgap of $\mathrm{TiO}_{2}$ by uplifting the position of VB while preserving the position of $\mathrm{CB}[20,33]$. Hence, we assume that $\mathrm{C}$-doping enhances the visible light absorption of $\mathrm{TiO}_{2}$ due to the effect of $\mathrm{C} 2 \mathrm{p}$ states hybridization. This result is also consistent with the calculation data given in the literature $[34,35]$.

\subsection{Cellular internalization of $\mathrm{C}^{-\mathrm{TiO}_{2}}$}

Cellular uptake determines PSs' bioactivity, which is crucial for photodynamic tumor therapy. Thus, we have studied $\mathrm{C}-\mathrm{TiO}_{2}$ internalization and accumulation in cancer cells. Cell uptake of $\mathrm{C}-\mathrm{TiO}_{2}$ by $\mathrm{HeLa}$ cells after $1 \mathrm{~h}$ of incubation was examined by confocal fluorescence microscopy (Fig. 3(b)). Since $\mathrm{TiO}_{2}$ is nonfluorescent and can't be detected by fluorescence imaging, we have presented the confocal micrograph as an overlay of the two channels-DIC and reflection channel in which the $\mathrm{C}-\mathrm{TiO}_{2}$ is shown in red for better observation. The micrograph revealed, besides cells' preserved morphology, the presence of the NPs in both extra- and intracellular space. Inside the cell, the particles seem to be mainly located around the cells' membrane, whereas, the particles' aggregates are placed in the outer cells' space. It has been reported that the internalization of $\mathrm{TiO}_{2}$ occurred through clathrin-mediated endocytosis, caveolin-mediated endocytosis, and macropinocytosis [36]. Xie et al. showed that surface charge plays an essential role in the uptake of NPs by HeLa cells by the mechanism that differs in dependence of their surface charge. They found that the clathrindependent pathway is related to the positively charged NPs, whereas the caveolin-dependent endocytic pathway is a dominant pathway of internalizing $\mathrm{TiO}_{2}-\mathrm{COOH}$ with a negative charge. For the negatively charged $\mathrm{C}-\mathrm{TiO}_{2}$, the last mentioned is the expected dominant pathway of the internalization. On the other hand, NPs are found at the extracellular surface of the cells despite extensive washing, as the clusters of NPs are probably remained attached to the cell membrane, being unable to be internalized.

\subsection{Cyto- and photo-cytotoxicity of $\mathrm{C}_{-} \mathrm{TiO}_{2}$ and blue light}

We assessed the viability of HeLa cells incubated with three different concentrations of $\mathrm{C}-\mathrm{TiO}_{2}$ by the modified MTT test after $48 \mathrm{~h}$. Figure 3(a) shows no cytotoxicity after $48 \mathrm{~h}$ of incubation with all tested concentrations, confirming that $\mathrm{C}-\mathrm{TiO}_{2}$ possess high biocompatibility. Therefore, we selected the maximal tested concentration $(160 \mu \mathrm{g} / \mathrm{mL})$ for further tests of the application of $\mathrm{C}-\mathrm{TiO}_{2}$ as the PSs.

In vitro photo-cytotoxicity was done by SRB assay after treatment with $\mathrm{C}-\mathrm{TiO}_{2}$ /blue light and $\mathrm{TiO}_{2} \mathrm{NPs}$ /blue light $(15 \mathrm{~min}, 120 \mu \mathrm{W})$ for comparison. The results are given in Fig. 4(a), and it is evident that the blue light illumination without $\mathrm{C}^{-\mathrm{TiO}_{2}}$ treatment also affected the cells' viability (67.8\% viable HeLa). However, the cells treated with $\mathrm{C}-\mathrm{TiO}_{2} /$ blue light showed a statistically significant decrease in cell viability compared to illuminated control, leaving $40 \%$ viable cells. In contrast, treatment with non-doped $\mathrm{TiO}_{2}$ NPs and blue light revealed no significant cytotoxicity compared to the blue light illumination control. Hence, HeLa cells' viability was considerably reduced by the combined treatment with $\mathrm{C}-\mathrm{TiO}_{2}$ and blue light illumination.

It was showed that low-intensity blue light irradiation could be effective in killing various types of cancer cells, such as lymphoma [37], skin tumors [38], colorectal cancer [39], human fibrosarcoma [40], and leukemia [41]. This treatment has several potential advantages over traditional $\mathrm{X}$-rays. For example, blue LED light affects cell growth, proliferation, and apoptosis of cancer cells by regulating
Fig. 3 The effect of $\mathrm{C}-\mathrm{TiO}_{2}$ on $\mathrm{HeLa}$ cells. C-TiO $\mathrm{T}_{2}$ dosedependent viability $(8,80$, and $160 \mu \mathrm{g} / \mathrm{mL}$ ) expressed as the percentage of the viability of control cells. Data were analyzed using one-way ANOVA with the Tukey's test and considered non-significant (ns) for $p \geq 0.05$ (a). Confocal microscopic images of HeLa cells treated with $\mathrm{C}-\mathrm{TiO}_{2}$ (red) for $1 \mathrm{~h}$ (b)
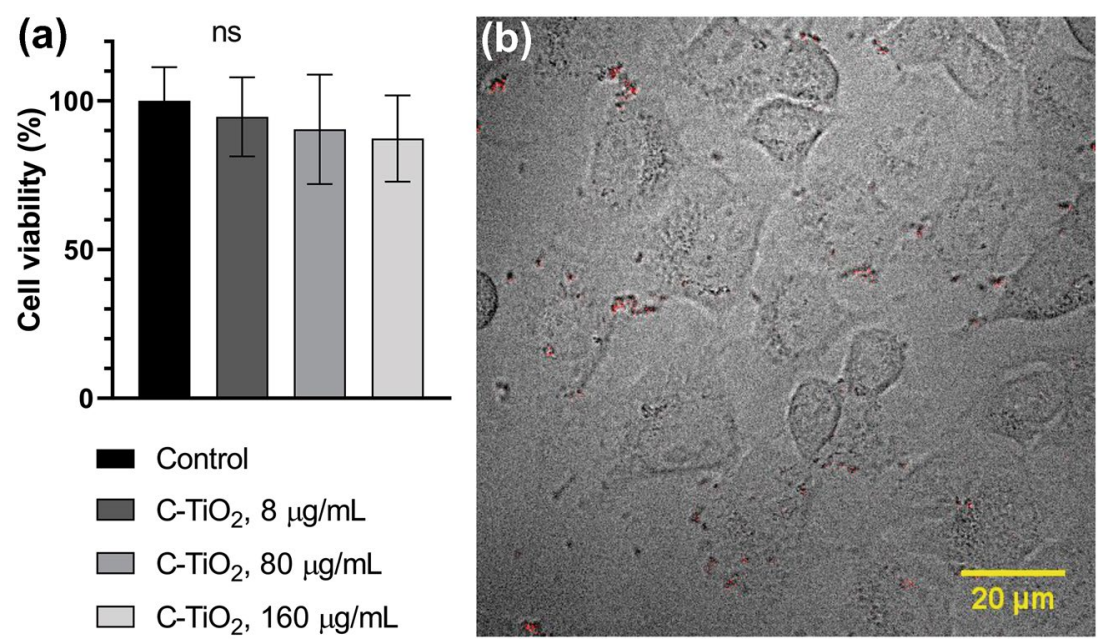

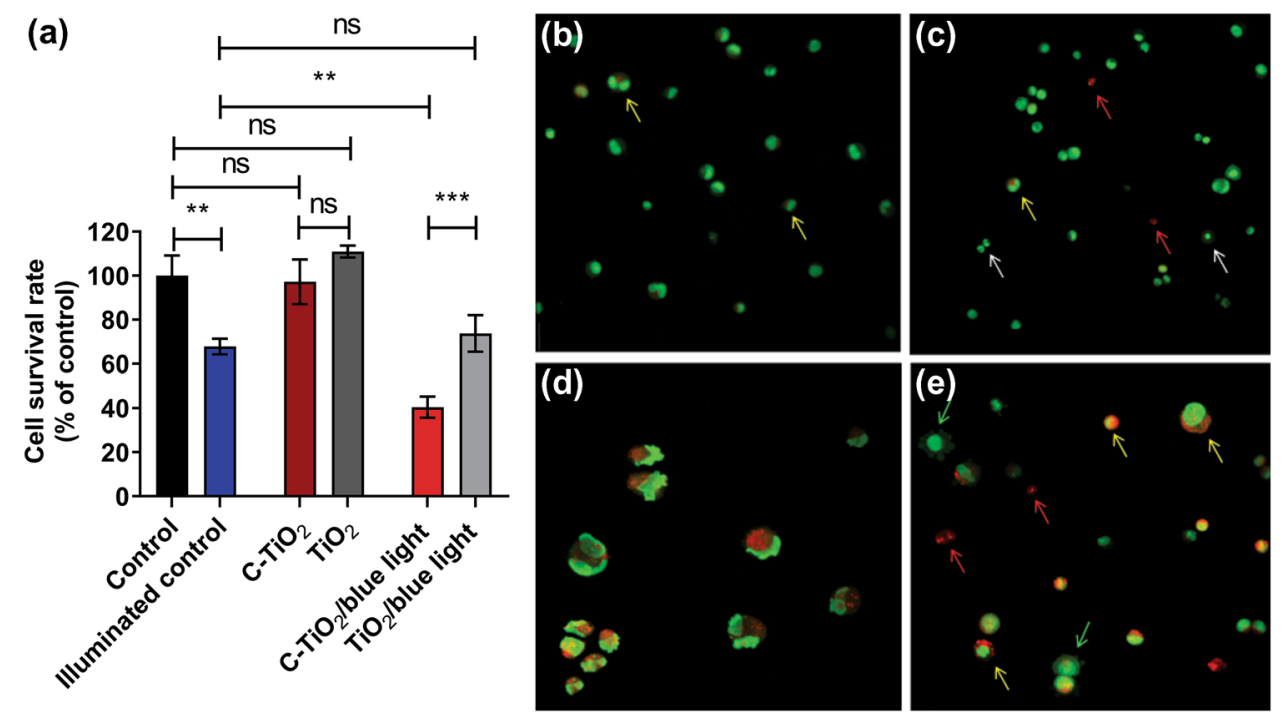

Fig. 4 The effect of the combined treatment of $\mathrm{C}-\mathrm{TiO}_{2} /$ blue light on the HeLa cells. Photo-cytotoxicity of C-TiO $2(160 \mu \mathrm{g} / \mathrm{mL})$ induced by blue light compared to non-doped $\mathrm{TiO}_{2}$ NPs (a). Data were analyzed using an one-way ANOVA with the Tukey's test; non-significant (ns) $-p \geq 0.05$, significant $-p<0.05\left(^{*}\right)$, and $p<0.001(* * *)$. From (b) to (e) representative photomicrographs of AO/PI stained HeLa cells: (b) untreated cells — green, ordinary morphology, the yellow

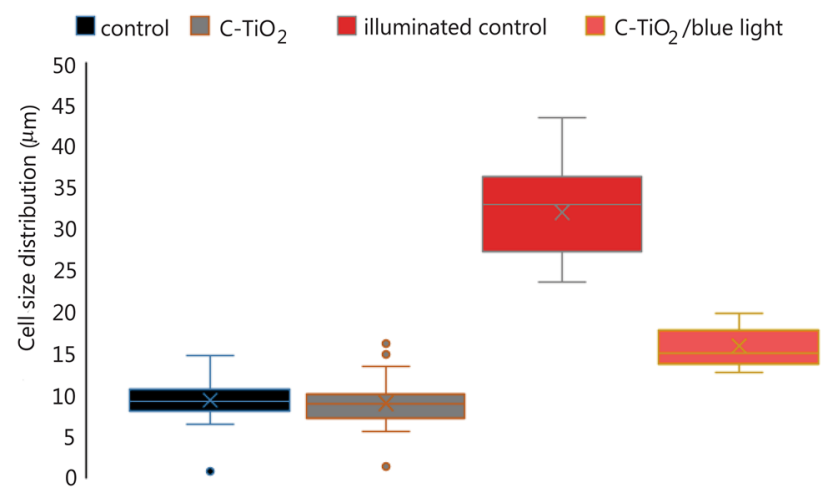

Fig. 5 Distribution of cell size $(\mu \mathrm{m})$ in different treatments measured by ISIS imaging software package (MetaSystems, Altlussheim, Germany)

autophagy and mitochondria-mediated signaling pathways. Moreover, a combination of blue LED light with drugs/PSs was promising in treating different cancers [42, 43].

We used live/dead AO/PI cell staining to obtain better insights into the cell death modalities of HeLa cells induced by treatment with a $\mathrm{C}-\mathrm{TiO}_{2} /$ blue light combination. The different staining pattern was revealed for cells without $\mathrm{C}-\mathrm{TiO}_{2}$ treatment, and blue light irradiation (Fig. 4(b)) and treated cells $\left(\mathrm{C}-\mathrm{TiO}_{2}\right.$, blue light, and blue light/C-TiO ${ }_{2}$; Fig. 4(c)-(e), respectively). Control HeLa cells displayed normal cell morphology and cell size $(9.4 \pm 0.4 \mu \mathrm{m})$ (Fig. 5.). arrows - cells with AVOs staining, (c) $\mathrm{C}_{-} \mathrm{TiO}_{2}$ treated cells - normal cells are present, but also early (white arrow) and late (red arrow) apoptotic cells are observed; (d) blue light illuminated HeLa cells and (e) $\mathrm{C}-\mathrm{TiO}_{2}$ /blue light treated HeLa cells - all types of cell death are seen as well as a large number of cells with AVOs (yellow arrows), indicating activation of autophagy. The scale bar is $30 \mu \mathrm{m}$

Acidic vesicular organelles (AVOs) were detected at a low level, around 5\% (Fig. 6.) attributed to basal autophagy described in HeLa cells [44]. After the treatment with $\mathrm{C}-\mathrm{TiO}_{2}, 2.9 \%$ of early (green cells with condensed nuclei) and $6.7 \%$ of late apoptotic cells (shrunken red cells with condensed nuclei and disturbed morphology) were observed (Figs. 4(c), Fig. 6.) with an average cell size of $9.0 \pm 0.5 \mu \mathrm{m}$, Fig. 5. Blue light-treated cells are large with deformed nuclei (32 $\pm 1 \mu \mathrm{m}$, Fig. 5.), cytoplasm swelling, and membrane blebbing (Fig. 4(d)), indicating necrosis (32.6\%, Fig. 6.) with many AVOs and suggesting the activation of cytoprotective autophagy in response to increased ROS production $[45,46]$. Previous research demonstrated that increased ROS production damages the subcellular compartments, triggering autophagy as a survival response. Autophagy is the recycling of damaged cellular compartments and biomolecules initiated in stressed cells to avoid apoptosis. When the cellular damage becomes too excessive, necrotic cell death is promoted [47]. Oh et al. [37] showed that blue LED irradiation induces cell death via the mitochondria-mediated pathway in conjunction with autophagy and increased intracellular $\mathrm{Ca}^{2+}$ levels. In our work, the combined blue light/C-TiO ${ }_{2}$ treatment (Fig. 4(e)) induced a significant increase in the number of cells with AVOs (yellow arrows) to $36.4 \%$, Fig. 6., which indicates activation of autophagy. Apoptosis and necrosis were also observed; $9.9 \%, 19.0 \%$, and $4.9 \%$ for the early, late apoptosis and necrosis, respectively (Fig. 6). Still, the moiety of necrotic cells treated with $\mathrm{C}-\mathrm{TiO}_{2} /$ blue light was lower 
Fig.6 Quantification of $\mathrm{AO} /$ PI stained HeLa cells presented as percentages of viable, early/ late apoptotic, and necrotic cells after the treatments with $\mathrm{C}-\mathrm{TiO}_{2}$, blue light, and the combined treatment with blue light/C- $\mathrm{TiO}_{2}$

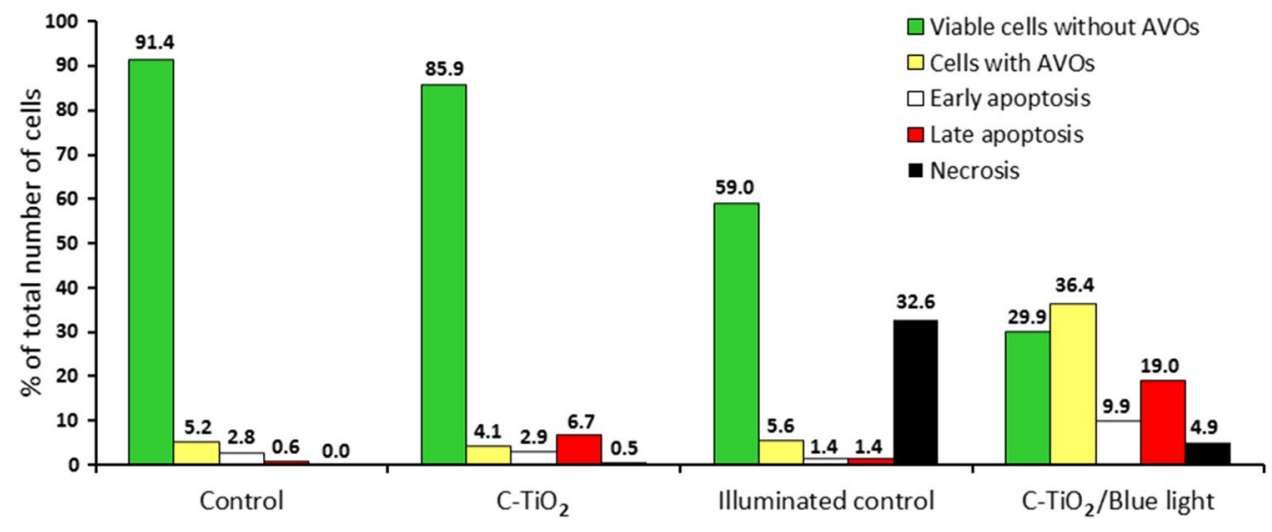

than illumination only, suggesting a switch to controlled cell death. The diameter of $\mathrm{C}-\mathrm{TiO}_{2} /$ blue light treated cells was also smaller (15.9 $\pm 0.4 \mu \mathrm{m}$, Fig. 5$)$. Considering that necrosis of malignant cells causes inflammation and promotes tumor spread and growth, a C-TiO $/$ /blue light combination provides a better outcome of anticancer therapy by inducing autophagy and a controlled cell death mechanism.

\subsection{Evaluation of photo-induced ROS generation}

We studied $\mathrm{C}-\mathrm{TiO}_{2}$ photo-induced ROS generation since that is the leading cell injury mechanism induced by different NPs [48]. Blue LED light is reported to have phototoxic and anti-proliferative effects through the generation of intracellular ROS. Increased levels of intracellular ROS expression were found in various types of tested cancer cells (mouse preadipocytes, prechondrocytes, myoblasts, mesenchymal stromal cells, lung cancer cells, insulinoma cells, fibroblasts, human cervix adenocarcinoma cells, macrophages differentiated from lymphocytes, and rat basophilic leukemia cells) after blue laser illumination [49]. Since the optical absorption edge shifted from $\mathrm{UV}$ to visible region for $\mathrm{C}-\mathrm{TiO}_{2}$, we expected that blue light illumination would enhance the $\mathrm{C}-\mathrm{TiO}_{2}$ induced ROS production, which is the leading cause of induced HeLa cells' death. To explore this hypothesis, we evaluated the effect of blue light illumination on intracellular ROS production with and without preincubation of the cells with $\mathrm{C}-\mathrm{TiO}_{2}$.

DCFH-DA was used to estimate blue light triggered intracellular ROS production for the HeLa cells incubated with $\mathrm{C}-\mathrm{TiO}_{2} .2^{\prime}, 7^{\prime}$-dichlorodihydrofluorescein diacetate $\left(\mathrm{H}_{2}\right.$ DCFDA) penetrates the cells and is essentially nonfluorescent. Upon the acetate groups' cleavage by intracellular esterases and oxidation, $\mathrm{H}_{2}$ DCFDA converts into the highly fluorescent DCF. Figure 7(a) shows that $\mathrm{C}-\mathrm{TiO}_{2}$ causes the most extensive intracellular ROS production equal to an illuminated positive control (TBHP) under the blue light illumination. Without the blue light irradiation, ROS levels of $\mathrm{HeLa}$ cells incubated with $\mathrm{C}-\mathrm{TiO}_{2}$ were unaltered compared to control (Fig. 7(a)), proving that $\mathrm{C}-\mathrm{TiO}_{2}$ could not stimulate intracellular ROS production in the dark. Blue light only also could cause intracellular ROS production. Still, the effect is less pronounced, indicating that the $\mathrm{C}-\mathrm{TiO}_{2} /$ blue light combination induced the most severe responses. These results agree with the cytotoxicity and photo-cytotoxicity results and may explain the outcomes shown in Fig. 4(a).

Upon the blue light illumination, the electrons are promoted from the $\mathrm{VB}$ to the $\mathrm{CB}$, generating highly reactive electron $\left(\mathrm{e}^{-}\right) /$hole $\left(\mathrm{h}^{+}\right)$pairs, which generated ROS in the cell culture medium. Produced ROS then randomly react with cellular lipids, proteins, and nucleic acids, damaging these macromolecules and leading to cell death. Higher ROS production ensures more efficient cell killing, Fig. 7(a) and Fig. 4(a).

The use of fluorescent probes and chemiluminescent assays is a simple and easy way of detecting intracellular ROS in cellular systems, but there are limitations and sources of artifacts [50]. In addition, ROS are short-lived and chemically distinct entities, difficult to detect in dynamic complex environments, such as biological systems. On the other hand, the EPR technique employed to study ROS generation mediated by nanomaterials has several advantages compared to fluorescent probes. Most importantly, EPR provides a more direct and chemically specific method for detecting ROS and identifying the exact type of free radical species, unlike fluorescent probes that give only information about the total amount of ROS produced by $\mathrm{C}-\mathrm{TiO}_{2}$ and blue light illumination. Therefore, to investigate the light-induced ROS liberation potential of C-TiO 2 , EPR spectroscopy was employed. The spin-trapping method was applied to detect hydroxyl radicals $\left({ }^{\circ} \mathrm{OH}\right)$ formation using DEPMPO as a spin-trap precursor. $\mathrm{C}-\mathrm{TiO}_{2}$ illuminated with the visible light $(120 \mu \mathrm{W})$ for $10 \mathrm{~min}$ in the presence of DEPMPO led to an immediate increase in the typical eight-line signal of the spin adduct DEPMPO/OH [51], indicating the formation of ${ }^{\bullet} \mathrm{OH}$, Fig. 7(b). The charge compensation mechanism dominates the formation of DEPMPO/OH from the reaction between DEPMPO and water on the $\mathrm{C}-\mathrm{TiO}_{2}$ surface. The generated 


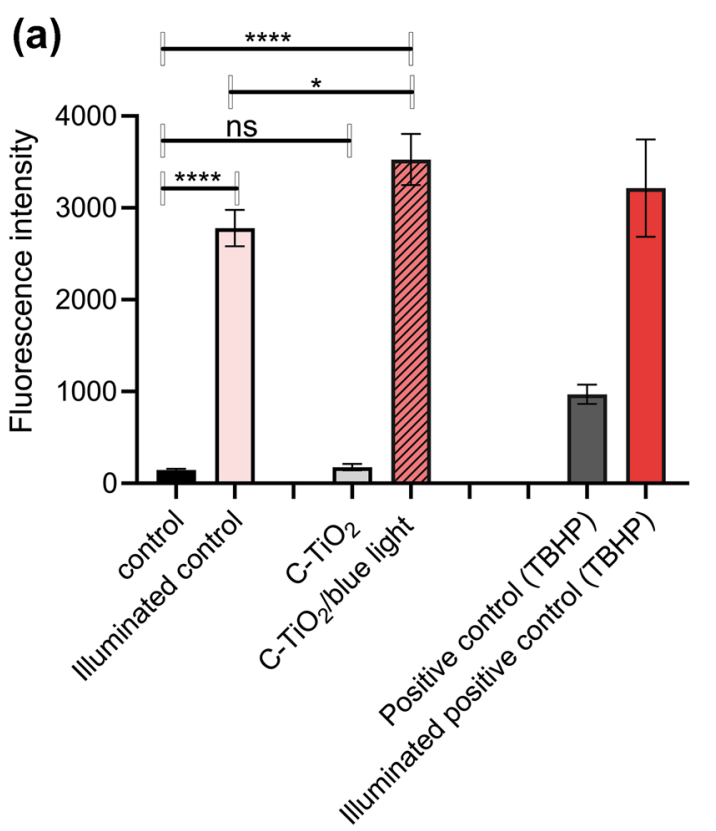

(b)
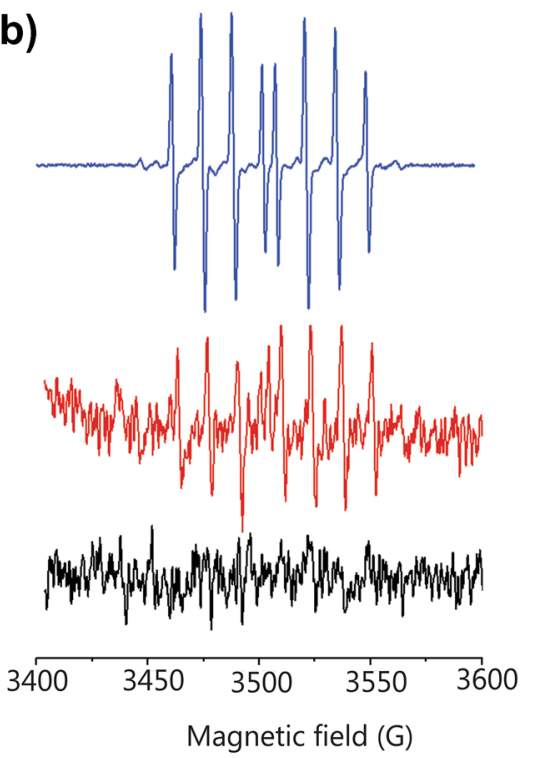

Fig.7 ROS generation evaluation. Intracellular ROS production assessed by the Fluorometric Assay Kit (a); ROS generation assessed by EPR (b). Fluorescence value of ROS in $\mathrm{C}^{-\mathrm{TiO}_{2}}$ preincubated $\mathrm{HeLa}$ cells followed by the blue light illumination. Samples were treated using a DCFH-DA probe, and the intracellular ROS production was quantified. The fluorescence value in $\mathrm{C}_{-} \mathrm{TiO}_{2}$ /blue light treated $\mathrm{HeLa}$ cells was compared to the values in control, illuminated control, and

${ }^{\bullet} \mathrm{OH}$ is the most reactive free radical with the highest 1-electron reduction potential and is primarily responsible for the aerobic organism's cytotoxic effect [52].

As already mentioned, when illuminated by blue light, photo-induced electrons and holes could be created and transferred to the surface of $\mathrm{C}-\mathrm{TiO}_{2}$. The photogenerated holes on the $\mathrm{C}-\mathrm{TiO}_{2}$ surface can further react with surrounding water to generate powerful ${ }^{\circ} \mathrm{OH}$ and other oxygen radicals. Multiple studies show that all forms of $\mathrm{TiO}_{2}$ (rutile, anatase, and P25) irradiated with light can produce hydroxyl radicals. Furthermore, physicochemical factors, including the size, shape, composition, and surface coating, and doping of NPs affect ROS levels significantly [53].

Both applied methods confirmed ROS production after illumination of $\mathrm{C}_{-} \mathrm{TiO}_{2}$ with visible light, leading to oxidative stress and HeLa cells death.

\section{Conclusion}

In the presented work, we demonstrated that carbon doping of $\mathrm{TiO}_{2}$ NPs resulted in the higher absorbance of $\mathrm{TiO}_{2} \mathrm{NPs}$ in the visible region. Moreover, our study confirmed the anticancer effects of $\mathrm{C}-\mathrm{TiO}_{2}$ /blue light combined treatment of HeLa cells. Furthermore, the significant photokilling effect
C-TiO 2 -treated cells. TBHP is a positive control. Data were analyzed using an one-way ANOVA with the Tukey's test and considered nonsignificant (ns) $-p \geq 0.05$, significant $-p<0.05(*)$, and $p<0.0001$ $(* * * *)$ (a). EPR spectra of DEPMPO/OH adduct obtained from $\mathrm{C}-\mathrm{TiO}_{2}$ water solution in the dark are shown with the black line. In contrast, EPR spectra with continuous visible light illumination are red. The blue line is the EPR spectrum of DEPMPO/OH adduct (b)

is associated with an increased ROS generation and the activation of autophagy as the predominant mechanism for cell death. Since autophagy is the desired cancer cell death mechanism, this system can be applied in cervical cancer therapy after fine-tuning towards better NPs uptake and short illumination times. However, further studies are needed to elucidate the effects of blue light with different power and illumination times, producing other photo-cytotoxic results. Also, in the continuation of this work, we will focus on the additional methods of modifying $\mathrm{C}-\mathrm{TiO}_{2}$, such as co-doping with other elements, to shift the bandgap towards the red-end of the spectrum.

Acknowledgements This work was supported by the Ministry of Education, Science and Technological Development of the Republic of Serbia (grant number 451-03-68/2020-14/200017, 451-03-68/2020-14/200146).

Authors' contributions Milica Matijević: investigation, validation, methodology, formal analysis, writing — original Draft, visualization. Jelena Žakula, Lela Korićanac, Marija Radoičić, Xinyue Liang, Đura Nakarada, Jelena Filipović Tričković, and Ana Valenta Šobot: investigation, formal analysis, writing—original Draft. Maja Stanković: writing: review \& editing, supervision. Miloš Mojović, Lan Mi, Marijana Petković and Milutin Stepić: resources, writing—review \& editing, funding acquisition. Maja D. Nešić: conceptualization, writingreview \& editing, methodology, project administration, supervision. 
Funding This work was supported by the Ministry of Education, Science and Technological Development of the Republic of Serbia, Serbian-Chinese bilateral project (grant number 451-00-478/2018-09/16), and by the Ministry of science and technology of the People's Republic of China (China-Serbia bilateral project SINO-SERBIA2018002).

Availability of data and material The datasets generated during and/or analyzed during the current study are available from the corresponding author on reasonable request.

Code availability Not applicable.

\section{Declarations}

Conflicts of interest The authors declare that they have no known competing financial interests or personal relationships that could have appeared to influence the work reported in this paper.

Ethics approval Not applicable.

Consent to participate All authors consented to participate.

Consent for publication All authors approved the version to be published.

\section{References}

1. Abbasi, A. (2019). Chapter $7-\mathrm{TiO}_{2}$-based nanocarriers for drug delivery. In S. S. Mohapatra, S. Ranjan, N. Dasgupta, R. K. Mishra, \& S. Thomas (Eds.), Nanocarriers for Drug Delivery (pp. 205-248). Amsterdam: Elsevier.

2. Flak, D., Yate, L., Nowaczyk, G., \& Jurga, S. (2017). Hybrid $\mathrm{ZnPc} @ \mathrm{TiO}_{2}$ nanostructures for targeted photodynamic therapy, bioimaging and doxorubicin delivery. Materials Science \& Engineering, C: Materials for Biological Applications, 78, 1072-1085. https://doi.org/10.1016/j.msec.2017.04.107

3. Nešić, M., Žakula, J., Korićanac, L., Stepić, M., Radoičić, M., Popović, I., Šaponjić, Z., \& Petković, M. (2017). Light controlled metallo-drug delivery system based on the $\mathrm{TiO}_{2}$-nanoparticles and Ru-complex. Journal of Photochemistry and Photobiology A: Chemistry., 347, 55-66. https://doi.org/10.1016/j.jphotochem. 2017.06.045

4. Yurt, F., Ocakoglu, K., Er, O., Soylu, H. M., Ince, M., Avci, C. B., Kurt, C. C., Sarı, F. A., Colak, S. G., \& Gunduz, C. (2019). Evaluation of photodynamic therapy and nuclear imaging potential of subphthalocyanine integrated $\mathrm{TiO}_{2}$ nanoparticles in mammary and cervical tumor cells. Journal of Porphyrins and Phthalocyanines, 23, 908-915. https://doi.org/10.1142/S1088424619500639

5. Wei, B., Dong, F., Yang, W., Luo, C., Dong, Q., Zhou, Z., Yang, Z., \& Sheng, L. (2020). Synthesis of carbon-dots@ $\mathrm{SiO}_{2} @ \mathrm{TiO}_{2}$ nanoplatform for photothermal imaging induced multimodal synergistic antitumor. Journal of Advanced Research., 23, 13-23. https://doi.org/10.1016/j.jare.2020.01.011

6. Sakib, S., Pandey, R., Soleymani, L., \& Zhitomirsky, I. (2020). Surface modification of $\mathrm{TiO}_{2}$ for photoelectrochemical DNA biosensors. Medical Devices \& Sensors., 3, e10066. https://doi.org/ $10.1002 / \mathrm{mds} 3.10066$

7. Wang, J., Xu, G., Zhang, X., Lv, J., Zhang, X., Zheng, Z., \& Wu, Y. (2015). Electrochemical performance and biosensor application of $\mathrm{TiO}_{2}$ nanotube arrays with mesoporous structures constructed by chemical etching. Dalton Transactions, 44, 7662-7672. https:// doi.org/10.1039/C5DT00678C
8. Mavrič, T., Benčina, M., Imani, R., Junkar, I., Valant, M., KraljIglič, V., \& Iglič, A. (2018). Chapter three-Electrochemical biosensor based on $\mathrm{tio}_{2}$ nanomaterials for cancer diagnostics. In A. Iglič, M. Rappolt, \& A. J. García-Sáez (Eds.), Advances in Biomembranes and Lipid Self-Assembly (pp. 63-105). London: Academic Press. https://doi.org/10.1016/bs.abl.2017.12.003

9. Shah, Z., Nazir, S., Mazhar, K., Abbasi, R., \& Samokhvalov, I. M. (2019). PEGylated doped- and undoped-TiO ${ }_{2}$ nanoparticles for photodynamic Therapy of cancers. Photodiagnosis and Photodynamic Therapy., 27, 173-183. https://doi.org/10.1016/j.pdpdt. 2019.05.019

10. Matijević, M., Nakarada, Đ, Liang, X., Korićanac, L., Rajsiglova, L., Vannucci, L., Nešić, M., Vranješ, M., Mojović, M., Mi, L., Estrela-Lopis, I., Böttner, J., Šaponjić, Z., Petković, M., \& Stepić, M. (2020). Biocompatibility of $\mathrm{TiO}_{2}$ prolate nanospheroids as a potential photosenzitizer in therapy of cancer. Journal of Nanoparticle Research, 22, 175. https://doi.org/10.1007/ s11051-020-04899-3

11. Chizenga, E. P., Chandran, R., \& Abrahamse, H. (2019). Photodynamic therapy of cervical cancer by eradication of cervical cancer cells and cervical cancer stem cells. Oncotarget, 10, 4380-4396. https://doi.org/10.18632/oncotarget.27029

12. Muroya, T., Suehiro, Y., Umayahara, K., Akiya, T., Iwabuchi, H., Sakunaga, H., Sakamoto, M., Sugishita, T., \& Tenjin, Y. (1996). Photodynamic therapy (PDT) for early cervical cancer, Gan to Kagaku ryoho. Cancer \& Chemotherapy., 23, 47-56.

13. ESMO, Cervical Cancer Ranked in the Top Three Cancers Affecting Women Younger Than 45 Years, (n.d.). Retrieved March 10, 2021, from https://www.esmo.org/oncology-news/cervical-cancer-ranked-in-the-top-three-cancers-affecting-women-young er-than-45-years.

14. Kubota, Y., Shuin, T., Kawasaki, C., Hosaka, M., Kitamura, H., Cai, R., Sakai, H., Hashimoto, K., \& Fujishima, A. (1994). Photokilling of T-24 human bladder cancer cells with titanium dioxide. British Journal of Cancer, 70, 1107-1111. https://doi.org/10. 1038/bjc. 1994.456

15. Zhang, A.-P., \& Sun, Y.-P. (2004). Photocatalytic killing effect of $\mathrm{TiO}_{2}$ nanoparticles on Ls-174-t human colon carcinoma cells. World Journal of Gastroenterology, 10, 3191-3193. https://doi. org/10.3748/wjg.v10.i21.3191

16. Cai, R., Hashimoto, K., Kubota, Y., \& Fujishima, A. (1992). Increment of photocatalytic killing of cancer cells using $\mathrm{TiO}_{2}$ with the aid of superoxide dismutase. Chemistry Letters, 21, 427-430. https://doi.org/10.1246/cl.1992.427

17. Galata, E., Georgakopoulou, E. A., Kassalia, M.-E., Papadopoulou-Fermeli, N., \& Pavlatou, E. A. (2019). Development of smart composites based on doped-tio ${ }_{2}$ nanoparticles with visible light anticancer properties. Materials (Basel). https://doi.org/10.3390/ ma12162589

18. Basavarajappa, P. S., Patil, S. B., Ganganagappa, N., Reddy, K. R., Raghu, A. V., \& Reddy, Ch. V. (2020). Recent progress in metaldoped $\mathrm{TiO}_{2}$, non-metal doped/codoped $\mathrm{TiO}_{2}$ and $\mathrm{TiO}_{2}$ nanostructured hybrids for enhanced photocatalysis. International Journal of Hydrogen Energy., 45, 7764-7778. https://doi.org/10.1016/j. ijhydene.2019.07.241

19. Etacheri, V., Di Valentin, C., Schneider, J., Bahnemann, D., \& Pillai, S. C. (2015). Visible-light activation of $\mathrm{TiO}_{2}$ photocatalysts: Advances in theory and experiments. Journal of Photochemistry and Photobiology C: Photochemistry Reviews., 25, 1-29. https:// doi.org/10.1016/j.jphotochemrev.2015.08.003

20. Ansari, S. A., Khan, M. M., Ansari, M. O., \& Cho, M. H. (2016). Nitrogen-doped titanium dioxide $\left(\mathrm{N}\right.$-doped $\left.\mathrm{TiO}_{2}\right)$ for visible light photocatalysis. New Journal of Chemistry, 40, 3000-3009. https:// doi.org/10.1039/C5NJ03478G

21. Li, Z., Mi, L., Wang, P.-N., \& Chen, J.-Y. (2011). Study on the visible-light-induced photokilling effect of nitrogen-doped $\mathrm{TiO}_{2}$ 
nanoparticles on cancer cells. Nanoscale Research Letters., 6, 356. https://doi.org/10.1186/1556-276X-6-356

22. Yang, C.-C., Wang, C.-X., Kuan, C.-Y., Chi, C.-Y., Chen, C.-Y., Lin, Y.-Y., Chen, G.-S., Hou, C.-H., \& Lin, F.-H. (2020). Using C-doped $\mathrm{TiO}_{2}$ nanoparticles as a novel sonosensitizer for cancer treatment. Antioxidants (Basel). https://doi.org/10.3390/antio x 9090880

23. Dong, F., Guo, S., Wang, H., Li, X., \& Wu, Z. (2011). Enhancement of the visible light photocatalytic activity of C-Doped $\mathrm{TiO}_{2}$ nanomaterials prepared by a green synthetic approach. Journal of Physical Chemistry C, 115, 13285-13292. https://doi.org/10. 1021/jp111916q

24. Ren, W., Ai, Z., Jia, F., Zhang, L., Fan, X., \& Zou, Z. (2007). Low temperature preparation and visible light photocatalytic activity of mesoporous carbon-doped crystalline $\mathrm{TiO}_{2}$. Applied Catalysis B: Environmental., 69, 138-144. https://doi.org/10.1016/j.apcatb. 2006.06.015

25. Vranješ, M., Kuljanin Jakovljević, J., Konstantinović, Z., Pomar, A., Stoiljković, M., Mitrić, M., Radetić, T., \& Šaponjić, Z. (2017). Shaped $\mathrm{Co}^{2+}$ doped $\mathrm{TiO}_{2}$ nanocrystals synthesized from nanotubular precursor: Structure and ferromagnetic behavior. Journal of Advanced Ceramics, 6, 220-229. https://doi.org/10.1007/ s40145-017-0233-5

26. Skehan, P., Storeng, R., Scudiero, D., Monks, A., McMahon, J., Vistica, D., Warren, J. T., Bokesch, H., Kenney, S., \& Boyd, M. R. (1990). New colorimetric cytotoxicity assay for anticancerdrug screening. JNCI Journal of the National Cancer Institute, 82, 1107-1112. https://doi.org/10.1093/jnci/82.13.1107

27. Abdel Wahab, S. I., Abdul, A. B., Alzubairi, A. S., Mohamed Elhassan, M., \& Mohan, S. (2009). In vitro ultramorphological assessment of apoptosis induced by zerumbone on (HeLa). Journal of Biomedicine and Biotechnology, 2009, 769568. https://doi. org/10.1155/2009/769568

28. Li, T.-H., \& Yan, H.-X. (2018). Antitumor- and apoptosis-inducing effects of pomolic acid against SK-MEL-2 human malignant melanoma cells are mediated via inhibition of cell migration and sub-G1 cell cycle arrest. Molecular Medicine Reports, 17, 10351040. https://doi.org/10.3892/mmr.2017.7977

29. Jackson, S. K., Liu, K. J., Liu, M., \& Timmins, G. S. (2002). Detection and removal of contaminating hydroxylamines from the spin trap DEPMPO, and re-evaluation of its use to indicate nitrone radical cation formation and $\mathrm{S}(\mathrm{N}) 1$ reactions. Free Radical Biology \& Medicine, 32, 228-232. https://doi.org/10.1016/ s0891-5849(01)00795-x

30. Dubey, R. S., \& Singh, S. (2017). Investigation of structural and optical properties of pure and chromium doped $\mathrm{TiO}_{2}$ nanoparticles prepared by solvothermal method. Results in Physics, 7, 1283-1288. https://doi.org/10.1016/j.rinp.2017.03.014

31. Singh Surah, S., Vishwakarma, M., Kumar, R., Nain, R., Sirohi, S., \& Kumar, G. (2019). Tuning the electronic band alignment properties of $\mathrm{TiO}_{2}$ nanotubes by boron doping. Results in Physics, 12, 1725-1731. https://doi.org/10.1016/j.rinp.2019.01.081

32. Huang, F., Yan, A., \& Zhao, H. (2016). Influences of doping on photocatalytic properties of $\mathrm{TiO}_{2}$ photocatalyst, semiconductor photocatalysis in materials. Mechanisms and Applications. https:// doi.org/10.5772/63234

33. Yu, J., Dai, G., Xiang, Q., \& Jaroniec, M. (2011). Fabrication and enhanced visible-light photocatalytic activity of carbon selfdoped $\mathrm{TiO} 2$ sheets with exposed 001 facets. Journal of Materials Chemistry, 21, 1049-1057. https://doi.org/10.1039/C0JM02217A

34. Guo, M., \& Du, J. (2013). Electronic and optical properties of C-N-codoped $\mathrm{TiO}_{2}$ : A first-principles GGA+U investigation. International Journal of Modern Physics B, 27, 1350123. https:// doi.org/10.1142/S0217979213501233

35. Zhao, C., Huang, D., \& Chen, J. (2018). DFT study for combined influence of C-doping and external electric field on electronic structure and optical properties of $\mathrm{TiO}_{2}(001)$ surface. Journal of Materiomics., 4, 247-255. https://doi.org/10.1016/j.jmat.2018.05. 003

36. Xie, J., Pan, X., Wang, M., Ma, J., Fei, Y., Wang, P.-N., \& Mi, L. (2016). The role of surface modification for $\mathrm{TiO}_{2}$ nanoparticles in cancer cells. Colloids and Surfaces. B, Biointerfaces, 143, 148-155. https://doi.org/10.1016/j.colsurfb.2016.03.029

37. Oh, P.-S., Hwang, H., Jeong, H.-S., Kwon, J., Kim, H.-S., Kim, M., Lim, S., Sohn, M.-H., \& Jeong, H.-J. (2016). Blue light emitting diode induces apoptosis in lymphoid cells by stimulating autophagy. International Journal of Biochemistry \& Cell Biology, 70, 13-22. https://doi.org/10.1016/j.biocel.2015.11.004

38. Oh, P.-S., Na, K. S., Hwang, H., Jeong, H.-S., Lim, S., Sohn, M.-H., \& Jeong, H.-J. (2015). Effect of blue light emitting diodes on melanoma cells: Involvement of apoptotic signaling. Journal of Photochemistry and Photobiology B: Biology, 142, 197-203. https://doi.org/10.1016/j.jphotobiol.2014.12.006

39. Yan, G., Zhang, L., Feng, C., Gong, R., Idiiatullina, E., Huang, Q., He, M., Guo, S., Yang, F., Li, Y., Ding, F., Ma, W., Pavlov, V., Han, Z., Wang, Z., Xu, C., Cai, B., Yuan, Y., \& Yang, L. (2018). Blue light emitting diodes irradiation causes cell death in colorectal cancer by inducing ROS production and DNA damage. The International Journal of Biochemistry \& Cell Biology., 103, 81-88. https://doi.org/10.1016/j.biocel.2018.08.006

40. Oh, P.-S., Kim, H.-S., Kim, E.-M., Hwang, H., Ryu, H. H., Lim, S., Sohn, M.-H., \& Jeong, H.-J. (2017). Inhibitory effect of blue light emitting diode on migration and invasion of cancer cells. Journal of Cellular Physiology, 232, 3444-3453. https://doi.org/ 10.1002/jcp.25805

41. Zhuang, J., Liu, Y., Yuan, Q., Liu, J., Liu, Y., Li, H., \& Wang, D. (2018). Blue light-induced apoptosis of human promyelocytic leukemia cells via the mitochondrial-mediated signaling pathway. Oncology Letters, 15, 6291-6296. https://doi.org/10.3892/ol.2018. 8162

42. Yang, M.-Y., Chang, C.-J., \& Chen, L.-Y. (2017). Blue light induced reactive oxygen species from flavin mononucleotide and flavin adenine dinucleotide on lethality of HeLa cells. Journal of Photochemistry and Photobiology B: Biology, 173, 325-332. https://doi.org/10.1016/j.jphotobiol.2017.06.014

43. Waer, C. N., Kaur, P., Tumur, Z., Hui, D. D., Le, B., Guerra, C., et al. (2020). Rosmarinic Acid/ Blue Light Combination Treatment Inhibits Head and Neck Squamous Cell Carcinoma In Vitro. Anticancer Res., 40, 751-758. https://doi.org/10.21873/anticanres. 14006

44. Tuloup-Minguez, V., Greffard, A., Codogno, P., \& Botti, J. (2011). Regulation of autophagy by extracellular matrix glycoproteins in HeLa cells. Autophagy, 7, 27-39. https://doi.org/10.4161/auto.7. 1.13851

45. Fang, C., Gu, L., Smerin, D., Mao, S., \& Xiong, X. (2017). The Interrelation between Reactive Oxygen Species and Autophagy in Neurological Disorders. Oxidative Medicine and Cellular Longevity., 2017, e8495160. https://doi.org/10.1155/2017/8495160

46. Yoboue, E. D., Sitia, R., \& Simmen, T. (2018). Redox crosstalk at endoplasmic reticulum (ER) membrane contact sites (MCS) uses toxic waste to deliver messages. Cell Death \& Disease, 9, 331. https://doi.org/10.1038/s41419-017-0033-4

47. Ullman, E., Fan, Y., Stawowczyk, M., Chen, H.-M., Yue, Z., \& Zong, W.-X. (2008). Autophagy promotes necrosis in apoptosisdeficient cells in response to ER stress. Cell Death and Differentiation, 15, 422-425. https://doi.org/10.1038/sj.cdd.4402234

48. Z. Yu, Q. Li, J. Wang, Y. Yu, Y. Wang, Q. Zhou, P. Li. (2020). Reactive oxygen species-related nanoparticle toxicity in the biomedical field. Nanoscale Res Lett, 15. https://doi.org/10.1186/ s11671-020-03344-7

49. Kushibiki, T., Hirasawa, T., Okawa, S., \& Ishihara, M. (2013). Blue laser irradiation generates intracellular reactive oxygen 
species in various types of cells. Photomedicine and Laser Surgery, 31, 95-104. https://doi.org/10.1089/pho.2012.3361

50. He, W., Liu, Y., Wamer, W. G., \& Yin, J.-J. (2014). Electron spin resonance spectroscopy for the study of nanomaterial-mediated generation of reactive oxygen species. Journal of Food and Drug Analysis., 22, 49-63. https://doi.org/10.1016/j.jfda.2014.01.004

51. Dvoranová, D., Barbieriková, Z., \& Brezová, V. (2014). Radical Intermediates in Photo-induced Reactions on $\mathrm{TiO}_{2}$ (An EPR Spin Trapping Study). Molecules, 19, 17279-17304. https://doi.org/10. 3390/molecules191117279

\section{Authors and Affiliations}

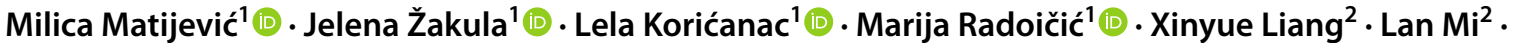

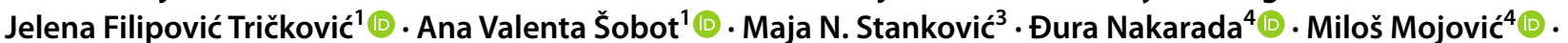
Marijana Petković ${ }^{10} \cdot$ Milutin Stepić ${ }^{10} \cdot$ Maja D. Nešić ${ }^{10}$

1 Vinča Institute of Nuclear Sciences-National Institute of the Republic of Serbia, University of Belgrade, 11001 Belgrade, Serbia

2 Department of Optical Science and Engineering, Fudan University, 200433 Shanghai, People's Republic of China
52. Krumova, K., \& Cosa, G. (2016). Chapter 1, Overview of Reactive Oxygen Species 1-21. https://doi.org/10.1039/9781782622 208-00001

53. Shi, H., Magaye, R., Castranova, V., \& Zhao, J. (2013). Titanium dioxide nanoparticles: A review of current toxicological data. Particle and Fibre Toxicology, 10, 15. https://doi.org/10.1186/ 1743-8977-10-15
3 Department of Chemistry, Faculty of Sciences and Mathematics, University of Niš, 18000 Niš, Serbia

4 Faculty of Physical Chemistry, University of Belgrade, 11000 Belgrade, Serbia 